\title{
Anti-inflammatory and antinociceptive activities of eugenol essential oil in experimental animal models
}

\author{
Apparecido N. Daniel, Simone M. Sartoretto, Gustavo Schmidt, Silvana M. Caparroz-Assef, \\ Ciomar A. Bersani-Amado, Roberto Kenji N. Cuman*
}

Departamento de Farmácia e Farmacologia, Universidade Estadual de Maringá, Av. Colombo 5790, 87020-900 Maringá-PR, Brazil

\begin{abstract}
RESUMO: “Atividades antiinflamatória e antinociceptiva do eugenol em modelos experimentais em animais". Eugenia caryophyllata, popularmente conhecida como "cravo-daíndia”, cresce naturalmente na Indonésia e é cultivada em várias partes do mundo, incluindo o Brasil. O cravo-da-índia é utilizado em culinária, em farmácia, perfumaria e cosméticos. O óleo essencial extraído do cravo-da-índia cujo principal componente é o eugenol tem sido utilizado em odontologia como anti-séptico e analgésico. O objetivo deste estudo foi avaliar as atividades antiinflamatória e antinociceptiva do eugenol de uso odontológico, administrado oralmente, em modelos experimentais in vivo. A atividade antiinflamatória do eugenol foi avaliada através do volume de exsudato e migração leucocitária no teste de pleurisia e do edema de pata de rato induzido pela carragenina. A atividade antinociceptiva foi avaliada através dos testes de contorções induzidas pelo ácido acético e da placa quente. O eugenol (200 e $400 \mathrm{mg} / \mathrm{kg}$ ) reduziu o volume de exsudato pleural sem interferir na contagem de leucócitos totais presentes na pleura. $\mathrm{Na}$ dose de $200 \mathrm{mg} / \mathrm{kg}$, o eugenol inibiu significativamente o edema de pata, 2-4 h após a injeção do agente flogístico. No teste da placa quente, a administração do eugenol $(100 \mathrm{mg} / \mathrm{kg})$ mostrou atividade significativa à reação de desconforto-tempo dependente, avaliada como a latência da resposta, inibida pela meperidina. Eugenol na doses de 50,75 e $100 \mathrm{mg} / \mathrm{kg}$ apresentou efeito antinociceptivo significativo no teste de contorções abdominais induzidas pelo ácido acético em comparação com o grupo controle. Os dados obtidos indicam que o eugenol apresenta atividade antiinflamatória e antinociceptiva periférica.
\end{abstract}

Unitermos: Eugenia caryophyllata, Syzygium aromaticum, Myrtaceae, atividade antiinflamatória, atividade antinociceptiva, óleo essencial, cravo-da-índia.

\begin{abstract}
Eugenia caryophyllata, popular name "clove”, is grown naturally in Indonesia and cultivated in many parts of the world, including Brazil. Clove is used in cooking, food processing, pharmacy; perfumery, cosmetics and the clove oil (eugenol) have been used in folk medicine for manifold conditions include use in dental care, as an antiseptic and analgesic. The objective of this study was evaluated the anti-inflammatory and antinociceptive activity of eugenol used for dentistry purposes following oral administration in animal models in vivo. The anti-inflammatory activity of eugenol was evaluated by inflammatory exudates volume and leukocytes migration in carrageenan-induced pleurisy and carrageenan-induced paw edema tests in rats. The antinociceptive activity was evaluated using the acetic acid-induced writhing and hot-plate tests in mice. Eugenol (200 and $400 \mathrm{mg} / \mathrm{kg}$ ) reduced the volume of pleural exudates without changing the total blood leukocyte counts. At dose of $200 \mathrm{mg} / \mathrm{kg}$, eugenol significantly inhibited carrageenan-induced edema, $2-4 \mathrm{~h}$ after injection of the flogistic agent. In the hot-plate test, eugenol administration $(100 \mathrm{mg} / \mathrm{kg})$ showed unremarkable activity against the time-todiscomfort reaction, recorded as response latency, which is blocked by meperidine. Eugenol at doses of 50,75 and $100 \mathrm{mg} / \mathrm{kg}$ had a significant antinociceptive effect in the test of acetic-acidinduced abdominal writhing, compared to the control animals. The data suggest that eugenol possesses anti-inflammatory and peripheral antinociceptive activities.
\end{abstract}

Keywords: Eugenia caryophyllata, Syzygium aromaticum, Myrtaceae, anti-inflammatory activity, antinociceptive activity, essential oil, clove.

\section{INTRODUCTION}

Eugenia caryophyllata L. Merr. \& Perry (syn.: Syzygium aromaticum) (clove) plant belongs to Myrtaceae families. Clove spice is a nail-shaped dried flower but of Eugenia caryophyllata Thunb. species. It 
is grown naturally in Indonesia and cultivated in many parts of the world, including Brazil (Costa, 1994; Corrêa et al., 1998; Agra et al., 2008). The plants have a strong phenolic smell and sharp acrid taste. Clove is used in cooking, food processing, pharmacy, perfumery and cosmetics. It contains essential oil at $15-20 \%$, tanene $13 \%$ and fixed oil $10 \%$. Non-essential ether extract constitutes $6-7 \%$. Essential oil of clove is a colorless or light yellowish fluid extract from dried flower buds by steam distillation. Through GC/MS analysis of clove essential oil, 36 components were identified (Chaieb et al., 2007). The highest concentration was of eugenol (88.58\%), eugenyl acetate (5.62\%) and $\beta$-cariophyllene $(1.38 \%)$. However, the differences in oil composition are correlated with different regions or countries where the plant is cultivated (Öztürk \& Özbek, 2005).

The eugenol is widely used and well known for its medicinal properties. Traditional uses of clove oil include use in dental care, as an antiseptic and analgesic (Oliveira et al., 2007). It is active against oral bacteria associated with dental caries and periodontal disease (Cai \& Wu, 1996) and effective against a large number of other bacteria (Burt \& Reinders, 2003; Larhsini et al., 2001; Cressy et al., 2003; Friedman et al., 2002) and virus (Kim et al., 2001). Previous studies have reported biological activities of eugenol including antifungal (Gayoso et al., 2005; Manohar et al., 2001; Chami et al., 2005), anticarcinogenic (Zeng et al., 1992), antiallergic (Kim et al., 1998; Corrêa et al., 2008), antimutagenic activity (Miyazawa \& Hisama, 2001), antioxidant (Ogata et al., 2000) and insecticidal (Park et al., 2000) properties. Eugenol has been used topically in dental practice to relieve pain arising from a variety of sources, including pulpits and dentinal hypersensitivity. In the present study, the anti-inflammatory and antinociceptive activities of eugenol used for dentistry purposes following oral administration in animal models in vivo were evaluated.

\section{MATERIAL AND METHODS}

\section{Plant material and extraction of the essential oil}

Eugenol (ANVISA $\mathrm{n}^{\circ}$ 10041120164) was purchased from S.S. White (Rio de Janeiro, Brazil). For the pharmacological assays, an aqueous suspension of eugenol was used.

\section{Animals}

Male Swiss mice weighing $25 \pm 5$ g were used in the experiments on antinociceptive activity and acute toxicity. Male Wistar rats weighing $200 \pm 30$ g were used for the evaluation of the anti-inflammatory activity. The animals were obtained from Central Animal House of the Universidade Estadual de Maringá. They were housed at $22 \pm 2{ }^{\circ} \mathrm{C}$ under a 12 hour light/ 12 hour dark cycle and had free access to water and food, before experimentation. Prior to the experiments, the animals were fasted overnight, with water provided ad libitum. The experimental protocols were approved by and were followed in accordance with the guidelines of the Ethical Committee in Animal Experimentation of the Universidade Estadual de Maringá.

\section{Carrageenan-induced paw edema in rats}

The anti-inflammatory test was evaluated by the carrageenan-induced paw edema test in the rat, according to the method of Winter et al. (1962). Male Wistar rats (190-230 g) were briefly anesthetized with ethyl ether and injected subplantarly into the right hind paw with $0.1 \mathrm{~mL}$ of suspension of carrageenan $(200 \mu \mathrm{g} /$ $\mathrm{mL}$ ) in isotonic saline. The left hind paw was injected with $0.1 \mathrm{~mL}$ of saline and used as a control. Paw volume was measured prior and 1,2 and $4 \mathrm{~h}$ after carrageenan administration, using a mercury plethysmograph (Ugo Basile, Italy). Eugenol (100, 200 and $400 \mathrm{mg} / \mathrm{kg}$ ) was orally administered 30 minutes prior to carrageenan injection. The control group received an equivalent volume of water. Indomethacin $(5 \mathrm{mg} / \mathrm{kg}$, p.o.) and celecoxib $(10 \mathrm{mg} / \mathrm{kg}$, p.o.) were used as the reference drugs.

\section{Carrageenan-induced pleurisy in rats}

The test was performed according to Vinegar et al. (1973). The groups of rats were pre-treated with eugenol (100, 200 and $400 \mathrm{mg} / \mathrm{kg}$, p.o.), indomethacin (5 mg/kg, p.o.) and celecoxib (10 mg/kg, p.o.) as the standard drugs, or water $(0.1 \mathrm{~mL}$, p.o. $)$ as the control. Thirty minutes later, all animals received an intrapleural injection of carrageenan $(200 \mu \mathrm{g} / \mathrm{animal})$. Four hours later the animals were anesthetized with ethyl ether. The pleural exudate was collected, the volume determined, and the pleural cavity was washed with $1.0 \mathrm{~mL}$ saline containing heparin $(10 \mathrm{IU} / \mathrm{mL})$. The number of migrating leukocytes in the exudate was determined with a Neubauer chamber. Results were expressed as mean \pm S.E.M. of exudate pleural volume and of counts of total leukocytes.

\section{Acetic acid-induced writhing test}

The antinociceptive activity of eugenol was assessed using the writhing test (abdominal constriction test), according to the method of Siegmund et al. (1957). Acetic acid solution $(10 \mathrm{~mL} / \mathrm{kg}, 0.6 \%)$ was injected intraperitoneally, and the constriction of the abdominal muscles together with stretching of the hind limbs was counted over a period of 20 minutes, starting immediately after acetic acid injection. The essential 
oil $(50,75$ and $100 \mathrm{mg} / \mathrm{kg}$, p.o.), indomethacin $(10 \mathrm{mg} /$ $\mathrm{kg}$, p.o. $)$ and celecoxib $(10 \mathrm{mg} / \mathrm{kg}$, p.o. $)$ as the standard drug (positive controls), and water $(0.3 \mathrm{~mL}$, p.o. $)$ as the negative control were administered 30 minutes before the acetic acid injection. Antinociceptive activity was expressed as the percentage of inhibition of abdominal constrictions between the control animals and the mice pre-treated with the oil.

\section{Hot-plate test}

The hot-plate test was performed to measure response latencies according to the method previously described (MacDonald et al., 1946). The hot-plate (Model DS 37, Ugo Basile, Italy) was maintained at $54.0 \pm 1{ }^{\circ} \mathrm{C}$. The time taken (sec) to cause a discomfort reaction (licking paws or jumping) was recorded as the response latency $0,15,30,60$ and 90 min after administration of eugenol $(50,75$ and $100 \mathrm{mg} / \mathrm{kg}$, p.o.), meperidine $(50 \mathrm{mg} / \mathrm{kg}$, i.p.) as the standard drug (positive control) or water $(0.3 \mathrm{~mL}$, p.o. $)$ as the negative control. A latency period of $25 \mathrm{sec}$ was defined as complete analgesia. The experiment was halted if the latency period was exceeded, in order to avoid injury.

\section{Statistical analysis}

All data are expressed as mean \pm S.E.M. Results were statistically analyzed using Student's t-test for unpaired data (two-tailed) or by one-way analysis of variance (ANOVA) followed Tukey test. P values $<0.05$ were considered statistically significant.

\section{RESULTS AND DISCUSSION}

In this study we evaluated the anti-inflammatory activity of eugenol in experimental models of inflammation (paw edema and pleurisy induced by carrageenan). The oral administration of eugenol at doses of $400 \mathrm{mg} / \mathrm{kg}$, significantly inhibited paw edema, 2-4 $\mathrm{h}$ after carrageenan injection and the inhibition rate was comparable to that of indomethacin and celecoxib. The results are presented in Figure 1.

It is related in literature that some essential oil extracted of plants exhibit an inhibitory effect of on pleural exudates formation (Siani et al., 1999; Vendruscolo et al., 2006). Similarly, in the pleurisy model, eugenol administered orally at doses of 200 and $400 \mathrm{mg} / \mathrm{kg}$ caused significant inhibition of fluid extravasation, but not on the leukocyte migration when compared with references drugs (Table 1). On the other hand, geranium, lemongrass and spearmint essential oil provoked inhibition of neutrophil accumulation in the peritoneal cavity (Abe et al., 2004).

It is well known that different mechanisms may be involved in the genesis of inflammatory reactions. The development of the inflammatory response induced by carrageenan (paw edema and pleurisy) is characterized by an initial stage (1-2 h) which is dependent on the release of histamine, serotonin and bradykinin, followed by a later stage (3-4 h) which is maintained principally by the release of prostanoids (Crunkhorn \& Meacock, 1971; Niemegeers et al., 1964). It has also been shown that nitric oxide (NO) has an important role as much as in the regulation of vascular permeability as in cell migration induced by proinflammatory agents, including carrageenan (Vinegar et al., 1982; Costa et al., 2008). In macrophages and other cell types, cytokines and lipopolysaccharide induce nitric syntase (iNOS) and cyclooxygenase-2 (COX-2). Both iNOS and COX-2 are responsible for the production of large proinflammatory mediators, nitric oxide and prostaglandins at the inflammatory site (Lee et al., 1992; Nussler \& Biliar, 1993). Eugenol showed similar antiinflammatory effects to COX antagonist (indomethacin) and COX-2 selective antagonist (celecoxib). The COX2 inhibitory effect of eugenol has been described by Huss et al., (2002) and in vitro by Kim et al., (2003) in LPS-stimulated mouse macrophage.

Two different analgesic testing methods were employed in the current investigation with the objective of identifying possible peripheral (acetic acid-induced writhing test) and central (hot-plate test) effects of the essential oil. Acetic acid causes an increase in the peritoneal fluid level of prostaglandins $\left(\mathrm{PGE}_{2}\right.$ and $\mathrm{PGF}_{2 \alpha}$ ), involving in part peritoneal receptors (Deraedt et al., 1980) and inflammatory pain by inducing capillary permeability (Amico-Roxas et al., 1984). Collier et al. (1968) postulated that acetic acid acts indirectly by inducing the release of endogenous mediators, which stimulate the nociceptive neurons. Indeed, traditional anti-inflammatory (NSAIDs) can inhibit COX in peripheral tissues and interfere with the mechanism of transduction of primary afferent nociceptors. Eugenol $(50,75$ and $100 \mathrm{mg} / \mathrm{kg}$ ) oral administration significantly decreased $(61.6,64.8$ and $88.3 \%$, respectively) the number of acetic acid-induced writhes in mice in comparison to the control group, as observed for indomethacin and celecoxib (Table 2). On the other hand, oral administration of eugenol $(50,75$ and $100 \mathrm{mg} / \mathrm{kg}$ ) failed to prolong latency time compared with control animals in mice in the hot-plate test (Figure 2). Meperidine $(50 \mathrm{mg} / \mathrm{kg}$, i.p.), the positive control used in this study caused significant antinociception effect. Eugenol exhibited significant antinociceptive activity against chemical stimuli (acetic acid tests), but not against thermal stimuli, suggesting that eugenol predominantly inhibits the peripheral pain mechanism. Similar results were observed by Kurian et al. (2006) after intraperitoneal administration of eugenol in mice. The analgesic effect was also demonstrated with others essential oils obtained from Zingiber officinale Roscoe (Vendruscolo et al., 2006), Lavandula angustifolia Mill L (Hajhashemi et al., 2003), Hypericum brasiliense 
Table 1. Effect of eugenol on pleurisy induced by intrapleural injection of carrageenan in male Wistar rats.

\begin{tabular}{|c|c|c|c|}
\hline Group & Exudate volume (mL) & \% Inhibition of edema & $\begin{array}{l}\left.\text { Leukocyte count (cells } / \mathrm{mm}^{3}\right) \\
\qquad \times 10^{3}\end{array}$ \\
\hline Control & $0.90 \pm 0.11$ & - & $62.6 \pm 4.8$ \\
\hline Indomethacin $5 \mathrm{mg} / \mathrm{kg}$ & $0.50 \pm 0.03^{*}$ & 44.5 & $61.5 \pm 6.0$ \\
\hline Celecoxib 10 mg/kg & $0.49 \pm 0.03^{* *}$ & 45.6 & $54.9 \pm 4.9$ \\
\hline Eugenol $100 \mathrm{mg} / \mathrm{kg}$ & $0.70 \pm 0.08$ & 22.2 & $53.9 \pm 3.4$ \\
\hline Eugenol $200 \mathrm{mg} / \mathrm{kg}$ & $0.54 \pm 0.07^{*}$ & 40.0 & $48.2 \pm 5.1$ \\
\hline Eugenol $400 \mathrm{mg} / \mathrm{kg}$ & $0.53 \pm 0.04^{*}$ & 41.1 & $45.7 \pm 5.9$ \\
\hline
\end{tabular}

Each value represents the mean number of leucocytes \pm SEM from 10-13 for each group.

${ }^{*} \mathrm{p}<0.05,{ }^{* *} \mathrm{p}<0.01$ compared to the control group (ANOVA, Tukey test).

Table 2. Effects of eugenol on acetic acid-induced writhing in mice.

\begin{tabular}{lcc}
\hline \multicolumn{1}{c}{ Group } & Number of writhings & Inhibition (\%) \\
\hline Control & $70.4 \pm 3.2$ & - \\
Indomethacin $10 \mathrm{mg} / \mathrm{kg}$ & $44.4 \pm 1.2^{*}$ & 36.9 \\
Celecoxib $10 \mathrm{mg} / \mathrm{kg}$ & $30.4 \pm 4.7^{*}$ & 56.8 \\
Eugenol $50 \mathrm{mg} / \mathrm{kg}$ & $27.0 \pm 6.6^{*}$ & 61.6 \\
Eugenol $75 \mathrm{mg} / \mathrm{kg}$ & $24.8 \pm 4.6^{*}$ & 64.8 \\
Eugenol $100 \mathrm{mg} / \mathrm{kg}$ & $6.2 \pm 1.1^{*}$ & 88.1 \\
\hline
\end{tabular}

Each value represents the mean \pm SEM from 7-9 for each group.

${ }^{*} \mathrm{p}<0.05$ compared to the control group (ANOVA, Tukey test).

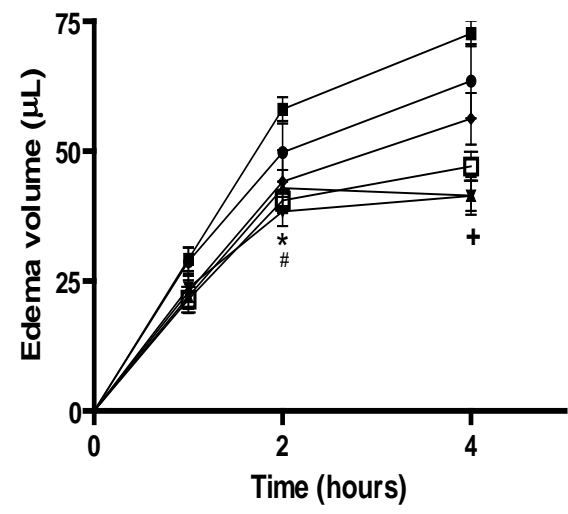

Figure 1. Effect of oral treatment with eugenol on the development of edema induced by intraplantar injection of carrageenan in rats ( $\mathrm{n}=8-10$ animals). Rats were treated orally with eugenol $(100,200$ and $400 \mathrm{mg} / \mathrm{kg}), 1 \mathrm{~h}$ prior to the injection of carrageenan $(200 \mu \mathrm{g})$. Indomethacin $(5 \mathrm{mg} / \mathrm{kg}$, p.o.) and celecoxib (10 mg/kg, p.o.) were used as the reference anti-inflammatory. Each column represents the mean volume of the paw \pm S.E.M., at 1,2 and $4 \mathrm{~h}$ after injection of the carrageenan. ${ }^{*} p<0.001 ;{ }^{\#} p<0.01 ;{ }^{+} p<0.01$, compared to the control group, treated with saline (ANOVA, Tukey test).

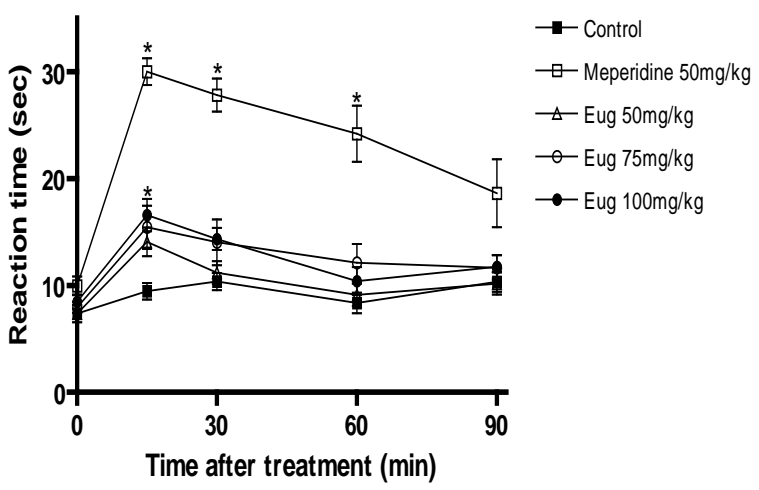

Figure 2. Effect of eugenol on the pain threshold of mice in the hot-plate test. The vehicle (control group), eugenol (50, 75 and $100 \mathrm{mg} / \mathrm{kg}$ ) and meperidine $(50 \mathrm{mg} / \mathrm{kg}$ ) were administered orally. The reaction time (sec) was measured 15, 30, 60 and 90 min after treatment. Each point represents the mean \pm S.E.M. reaction time.*p $<0.001$ compared to the control group (ANOVA, Tukey test). 
willd (Perazzo et al., 2008) and Satureja hortensis L (Hajhashemi et al., 2002).

Our data demonstrated that the antiinflammatory and antinociceptive activities of eugenol might be partially related to inhibition of prostaglandin synthesis or release of other endogenous mediators. Overall, our data provide support for the popular use of eugenol in folk medicine for some inflammatory and pain ailments.

\section{ACKNOWLEDGEMENTS}

This study was supported by the grants from the Fundação Araucária, Paraná, Brazil. We thank Mr. Jailson Araujo Dantas and Mrs. Célia Regina Miranda for technical assistance.

\section{REFERENCES}

Abe S, Maruyama N, Hayama K, Inouye S, Oshima H, Yamaguchi H 2004. Supression of neutrophil recruitment in mice by geranium essential oil. Mediat Inflamm 13: 21-24.

Agra MF, Silva KN, Basílio IJLD, França PF, Barbosa-Filho JM 2008. Survey of medicinal plants used in the region Northeast of Brazil. Rev Bras Farmacogn 18: 472-508.

Amico-Roxas M, Caruso A, Trombadore S, Scifo R, Scapagine U 1984. Gangliosides antinociceptive effects in rodents. Arch Int Pharmacodyn Ther 272: 103-117.

Burt SA, Reinders RD 2003. Antibacterial activity of selected plant essential oil against Escherichia coli O157:H7. Lett Appl Microbiol 36: 162-167.

Cai L, Wu CD 1996. Compounds from Syzygium aromaticum possessing growth inhibitory activity against oral pathogens. J Nat Prod 59: 987-990.

Chaieb K, Hajlaoui H, Zmantar T, Kahla-Nakbi AB, Rouabbhia M, Mahdouani K, Bakhrouf A 2007. The chemical composition and biological activity of clove essential oil, Eugenia caryophyllata (Syzigium aromaticum L. Myrtaceae): a short review. Phytother Res 21: 501-506.

Chami F, Chami N, Bennis S, Bouchikhi T, Remmal A 2005. Oregano and clove essential oils induce surface alteration of Saccharomyces cerevisiae. Phytother Res 19: 405-408.

Collier HOJ, Dinnen LC, Johnson CA, Schneider C 1968. The abdominal constriction response and its suppression by analgesic drugs in mouse. Brit $J$ Pharmacol Chemother 32: 295-310.

Corrêa AD, Siqueira-Batista R, Quintas LEM. 1998. Plantas Medicinais: do cultivo à terapêutica. Petrópolis.

Corrêa MFP, Melo GO, Costa SS 2008. Substâncias de origem vegetal potencialmente úteis na terapia da Asma. Rev Bras Farmacogn 18 (Supl.): 785-797.

Costa AF 1994. Farmacognosia. Lisboa: Calouste Gulbenkian.

Costa JFO, David JPL, David JM, Giulietti AM, Queiroz LP, Santos RR, Soares MBP 2008. Immunomodulatory activity of extracts from Cordia superb Cham. and Cordia rufescens A. DC. (Boraginaceae), plant species native from Brazilian Semi-arid. Rev Bras
Farmacogn 18: 11-15.

Cressy HK, Jerret AR, Osborne CM, Bremer PJ 2003. A novel method for the reduction of number of Listeria monocytogenes cells by freezing in combination with an essential oil in bacteriological media. $J$ Food Protect 66: 390-395.

Crunkhorn P, Meacock SC 1971. Mediators of inflammations induced in the rat paw by carrageenan. Brit $J$ Pharmacol 42: 392-402.

Deraedt R, Jougney S, Delevalcee F, Falhout M 1980. Release of prostaglandin $\mathrm{E}$ and $\mathrm{F}$ in an algogenic reaction and its inhibition. Eur J Pharmacol 51: 17-21.

Friedman M, Henika PR, Mandrell RE 2002. Bactericidal activities of plant essential oils and some of their isolated constituents against Campylobacter jejuni, Escherichia coli, Listeria monocytogenes, and Salmonella enterica. J Food Protect 65: 1545-1560.

Gayoso CW, Lima EO, Olivera VT, Pereira FO, Souza EL, Lima EL, Navarro DF 2005. Sensitivity of fungi isolated from onichomicosis to Eugenia caryophyllata essential oil and eugenol. Fitoterapia 76: 247-249.

Hajhashemi V, Ghannadi A, Pezeshkian SK 2002. Antinociceptive and anti-inflammatory effects of Saruteja hortensis L. extracts and essential oil. $J$ Ethnopharmacol 82: 83-87.

Hajhashemi V, Ghannadi A, Sharif, B 2003. Anti-inflammatory and analgesis properties of the leaf extracts and essential oil of Lavandula angustifolia Mill. $J$ Ethnopharmacol 89: 67-71.

Huss U, Ringbom T, Perera P, Bohlin L, Vasänge M 2002. Screening of ubiquitous plant constituents for COX2 inhibition with a scintillation proximity based assay. J Nat Prod 65: 1517-1521.

Kim HM, Lee EH, Hong SH, Song HJ, Shin MK, Kim SH, Shin TY 1998. Effect of Syzygium aromaticum extract on immediate hypersensitivity in rats. $J$ Ethnopharmacol 60: 125-131.

Kim HJ, Lee JS, Woo ER, Kim MK, Yang BS, Yu YG, Park H, Lee YS 2001. Isolation of virus-cell fusion inhibitory components from Eugenia caryophyllata. Planta Med 67: 277-279.

Kim SS, Oh OJ, Min HY, Park EJ, Kim Y, Park HJ, Han YN, Lee SK 2003. Eugenol suppresses cyclooxygenase expression in lipopolysaccharide-stimulated mouse macrophage RAW264.7 cells. Life Sci 73: 337-348.

Kurian R, Arulmozhi DK, Veeranjaneyulu A, Bodhankar SL 2006. Effect of eugenol on animal models of nociception. Indian J Pharmacol 38: 341-345.

Larhsini M, Oumoulid L, Lazrek HB, Wataleb S, Bousaid M, Bekkouche K, Jana M 2 001. Antibacterial activity of some Maroccan medicinal plants. Phytother Res 15: 250-252.

Lee SH, Soyoola E, Chanmungam P, Hart S, Sun W, Zhong H, Liou S, Simmons D, Hwang D 1992. Selective expression of mitogen-inducible cyclooxygenase in macrophages stimulated with lipopolysaccaride. $J$ Biol Chem 267: 25934-25938.

MacDonald AD, Woolfe G, Bergel F, Morrison AL, Paroli E, Rinderknecht H 1946. Analgesis action of pethidine and related compounds. Brit J Pharmacol Chemother 1: 4-14.

Manohar V, Ingram C, Gray J, Talpur NA, Echard BW, Bagchi D, Preuss HG 2001. Antifungal activities 
of origanum oil against Candida albicans. Mol Cel Biochem 228: 111-117.

Miyazawa M, Hisama M 2001. Suppression of chemical mutagen induced SOS response by alkylphenols from clove (Syzygium aromaticum) in Salmonella typhymurium TA1535/pSK1002 umu test. J Agric Food Chem 49: 4019-4025.

Niemegeers CJ, Verbruggen FJ, Janssen PA 1964. Effect of various drugs on carrageenan-induced oedema in the rat hind paw. J Pharm Pharmacol 16: 810-816.

Nussler AK, Billiar TR 1993. Inflammation, immunoregulation, and inducible nitric oxide synthase. J Leukocyte Biol 54: 171-178.

Ogata M, Hoshi M, Urano S, Endo T 2000. Antioxidant activity of eugenol and related monomeric and dimeric compounds. Chem Pharm Bull 48: 1467-1469.

Oliveira FQ, Gobira B, Guimarães C, Batista J, Barreto M, Souza M 2007. Espécies vegetais indicadas na odontologia. Rev Bras Farmacogn 17: 466-476.

Öztürk A, Özbek H 2005. The anti-inflammatory activity of Eugenia caryophyllata essential oil: an animal model of anti-inflammatory activity. Eur J Gen Med 4: 159163.

Park IK, Lee HS, Lee SG, Park JD, Ahn YJ 2000. Insecticidal and fumigant activities of Cinnamomum cassia bark-derived material against Mechoris ursulus (Coleoptera Attelabidae). J Agric Food Chem 48: 2528-2531.

Perazzo FF, Lima LM, Padilha MM, Rocha LM, Sousa PJC, Carvalho JCT 2008. Anti-inflammatory and analgesic activities of Hypericum brasiliense (Willd) standardized extract. Rev Bras Farmacogn 18: 320325.

Siani AC, Ramos MFS, Menezes-de-Lima Jr O, Ribeirodos-Santos R, Fernadez-Ferreira E, Soares ROA, Rosas EC, Susunaga GS., Guimaraes AC, Zoghbi MGB, Henriques MGMO 1999. Evaluation of anti-inflammatory-related activity of essential oils from the leaves and resin of species of Protium. $J$ Ethnopharmacol 66: 57-69.

Siegmund E, Cadmus R, Lu G 1957. A method for evaluating both non-narcotics and narcotics analgesics. Proc Soc Exp Biol Med 95: 729-731.

Vendruscolo A, Takaki I, Bersani-Amado LE, Dantas JA, Bersani-Amado CA, Cuman RKN 2006. Studies on anti-inflammatory and antinociceptive activities of Zingiber officinale Roscoe essential oil in experimental animal models. Indian J Pharmacol 38: 58-59.

Vinegar R, Truax JF, Selph JL 1973. Some quantitative temporal characteristics of carrageenan-induced pleurisy in the rat. Proc Soc Exp Biol Med 143: 711714.

Vinegar R, Truax JF, Selph JL, Voelker FA 1982. Pathway of onset, development, and decay of carrageenan pleurisy in the rat. Fed Proc 41: 2588-2595.

Winter CA, Risley EA, Nuss GV 1962. Carrageenan-induced edema in the hindpaw of the rat as an assay for antiinflammatory drugs. Proc Soc Exp Biol Med 111: 544-547.

Zeng GQ, Kenney PM, Lam LKT 1992. Sesquiterpenes from clove (Eugenia caryophyllata). J Nat Prod 55: 991003. 